\title{
HISTORIA DAS MENTALIDADES E NOVA HISTORIA POLÍTICA: UNHA CONFLUENCIA NECESARIA
}

\author{
Por \\ ARACELI OTERO FERNÁNDEZ
}

Hai máis de quince anos, Jacques Le Goff publicaba un artigo de suxestivo título: «¿Es la política todavía el esqueleto de la historia?»1: $\mathrm{Nel}$, o recoñecido medievalista reflexionaba verbo do desprestixio da historia política, rexeitada non só polos annalistas - escola de extraordinaria influencia durante o século XX, «culpable» do mantemento, durante decenios, de certos prexuízos e enfoques difíciles de superar; mais tamén de aportacións novidosas e esenciais na comprensión da producción historiográfica de boa parte do século- senón tamén por suposto, polo marxismo, para quen o suxeito individual - e este era tradicionalmente o obxecto dunha historia política pouco reflexiva, encorsetada, pura erudición e «evenement»—- se mergullaba irremisiblemente en superestructu-

\footnotetext{
' Editado en España en Lo maravilloso y lo cotidiano en el occidente Medieval, Barcelona 1985, pp. 163-178. O artigo é de 1971; Le Goff nesas datas reflexiona sobre diversas cuestións historiográficas, e en varios traballos trata as posibilidades da antropoloxía histórica, da historia das mentalidades e da historia política renovada. Ocorre que só o relativo as mentalidades tivo eco, mentres que o que aquí nos ocupa foi maioritariamente ignorado. Le Goff, como case cincuenta anos atrás Febvre e Bloch, tanteou varias vías, abriu portas diferentes aínda que só unha se traspasou.
}

"CUADERNOS DE ESTUDIOS GALLEGOS", Tomo XLIII, Fascículo 108, Santiago 1996. 
ras e infraestructuras que non eran a «gaiola flexible» da que algúns historiadores falan ${ }^{2}$, senón cámara acoirazada da que era imposible saír, e o propio intento de facelo.

En pouco máis de quince páxinas, Le Goff debuxaba con trazos contundentes a regresión que a historia política sofre no século XX, especialmente dramática tendo en conta o extraordinario pulo que ata entón a fixera practicamente centro e alma do traballo do historiador - analítico ou non-. Ata o século XX, o trono da historia foi ocupado pola política; mais o seu reinado na nova centuria ía ser breve. As novas ciencias sociais, que con ansias e efectos renovadores no ámbito do coñecemento desenvolverán un Vidal de La Blanche, un Simiand ou un Durkheim permiten, intencionadamente ou non, a chegada dunha nova historia. As esixencias e intereses serán desde agora diferentes. O golpe de gracia daráno os «annalistas», verdadeiros «verdugos» que detestan o trinomio formado pola historia política, a historia narrativa e a crónica ou historia dos episodios e acontecementos. A través da súa revista e das súas obras individuais -nos anos 20 e 30-, os primeiros Annales pretenden e consiguen abeirar o tradicional xeito de facer e escribir a historia; sitúan como meta a historia total - oposta por definición a HISTORIA positivista-, utopía irrealizable ${ }^{3}$, certamente, mais indispensable desde entón para todo historiador. Converten o económico, social e mental nos paladíns da súa loita. A longa duración que eses tres conceptos suxerían contrapúñase ó tempo curto que a tradicional historia política consideraba; o breve e fútil dun acontecemento, ¿que importancia pode ter, fronte ó que pervive ou se modifica a longo prazo, o que podemos rastrexar, cotexar,

\footnotetext{
${ }^{2}$ Por exemplo, Giovanni Levi, nunha entrevista en Manuscrits, «Antropología y microhistoria. Conversación con Giovanni Levi», nº 11, xaneiro, 1993, pp. 15-28, refírese neses termos á capacidade que as circunstancias dunha época teñen de constreñir e limitar, determinar as accións individuais; mais tamén a posibilidade de empuxar os barrotes da gaiola e moverse, non sen dificultades ou novas limitacións, con maior autonomía.

${ }^{3}$ A meta de historia total e o seu carácter utópico, digna en principio, tivo consecuencias nefastas; funcionou exactamente á inversa do que pretendía e limitou enormemente os logros posibles. A globalidade preconizada viuse progresivamente desmigallada en micrototalidades sen conexión entre sí. O dramatismo da cuestión é tanto maior canto que se constituíu no paradigma máis compartido e menos aplicado da historiografía do $\mathrm{XX}$, marxismo incluído.
}

"CUADERNOS DE ESTUDIOS GALLEGOS", Tomo XLIII, Fascículo 108, Santiago 1996. 
«aritmetizar» e medir nun período de tempo longo ${ }^{4}$. Neste contexto, non só se cultivaron con interese desusado ata entón os campos do social difícil de limitar ou definir propiamente- e o económico. As mentalidades eran campo aboado: o mental presenta características que o fan susceptible - case máis que calquera outra faceta da actividade humanade ser «invadido» por ese novo historiador dada a longa duración que o acolle e a colectividade á que afecta. Polo tanto, se grande era a distancia historia política / historia social e económica, maior e irreductible a que afastaba o político - pexorativamente entendido — do mental. A longa duración/colectivo opónse frontalmente ó curto acontecemento/suxeito (as máis das veces reis ou raíñas, guerreiros e outros personaxes que levaban sobre si o peso da HISTORIA con maiúsculas).

O camiño a seguir por estes primeiros Annales estaba trazado; do mesmo xeito, o historiador «serio» tería que se consciente do peche -necesario- desoutra - ata entón - única vía, a historia política. A biografía, raíña consorte, correrá unha sorte similar canto que o seu obxecto é se cabe máis particular; partidista, reduccionista e «historizante» ${ }^{5}$. O papel xogado por outras disciplinas sociais no proceso bocexado é decisivo; a partir de 1929, a vontade de moitos dos especialistas, «buque insignia» das mesmas, manifestábase na necesidade de interdisciplinaridade. Nese novo marco de relación o papel da historia será central, como eixo en torno ó que xirarán as restantes disciplinas, segundo a postura dos historiadores; para os sociólogos, sería a súa a disciplina centro de gravidade. Sexa como fose, e independentemente de xerarquías ou supremacías, a necesidade de comunicación entre elas recoñécese como imprescindible e irrenunciable.

A novos presupostos, novos métodos. Mentres os primeiros Annales e a súa anovadora historia florecían, a historia política e todo o que ela tiña que ver pasaba a formar parte do recordo, das «mazmorras» do castelo da historia.

\footnotetext{
${ }^{4}$ Non entraremos aquí nas circunstancias históricas e personais que os analistas viviron e que indubidablemente contribuíron a conformar o seu concepto de historia, tempo, acontecemento...

${ }^{5}$ Evidentemente, as anovacións historiográficas non só veñen dadas polos profesionais da historia e os seus teóricos, un círculo reducido; tamén o ambiente intelectual, as tendencias culturalmente dominantes nun determinado momento, teñen eco.
}

"CUADERNOS DE ESTUdIOS GALLEGOS", Tomo XLIII, Fascículo 108, Santiago 1996. 
O quefacer historiográfico proposto polos annalistas implica novos e diversos obxectos e consecuentemente novas metodoloxías que propiciarán o aproveitamento e explotación profunda de fontes que ata entón non se consideraran sequera complemento ás indagacións do historiador profisional. O texto (tratado como «monumento» polos positivistas) é, efectivamente, material de primeira man, mais tamén o son as produccións artísticas —entendidas no máis amplo senso-, literarias, iconográficas, que abrirán novas perspectivas na análise e comprensión global dunha sociedade; a través delas, e tamén do «ausente» nas mesmas, rastréxanse actitudes colectivas, mentais, sensibilidades e comportamentos difíciles de percibir, por exemplo, nun texto emanado das institucións a través das que as elites exercen o seu poder. E así chega en 1924 unha obra pioneira, Los Reyes taumaturgos, de Marc Bloch; no seu afán de historia total, o campo das mentalidades colectivas destaca por mérito propio. $\mathrm{O}$ estudio dunha institución como a monarquía, de longuísima duración no tempo, superviviente a diversas mutacións, cunha enorme capacidade de adaptación e presente - de xeito continuo ou intermitente - na maior parte da Europa Occidental, xustifícase en si mesmo. Ademais é unha vía de penetrar na investigación da historia política non sospeitosa de positivista; certamente, a política entendida como simple sucesión de reis ou institucións era centro de críticas furibundas e xustificadas polos annalistas; mais o político, como o simbólico, o mental, e económico, era un elemento máis, singular e insustituíble, na percura desa totalidade histórica por eles reivindicada. Como el mesmo explica:

«para comprender lo que fueron las monarquías de antaño, para explicar sobre todo su vasto ascendiente sobre los hombres, no es suficiente aclarar, hasta el último detalle, el mecanismo de organización administrativa, judicial, financiera, que impulsieron a sus súbditos; no es suficiente analizar en abstracto o tratando de deducirlos de algunos grandes teóricos, los conceptos de absolutismo o de derecho divino. Es preciso entrar también en las creencias y hasta en las fábulas que florecieron alrededor de las casas reinantes. En muchos aspectos, todo este folklore nos dice más que cualquier tratado doctrinal» ${ }^{6}$.

${ }^{6}$ En Marc Bloch, Los Reyes taumaturgos, p. 27, ed. española 1988, México. 
De novo reacciona contra o superficial, reivindica a historia problema, constituída por un obxecto complexo e multiforme, de variables ocultas á vista, pero rastrexables a través da psicoloxía colectiva, da antropoloxía e o folklore, e incluso da medicina. Non se trata de historia política tradicional -aínda que Bloch pretende, segundo as suas propias palabras, constribuír ó coñecemento da historia política de Occidente-. É fundamentalmente unha historia das mentalidades colectivas, de comportamentos comúns ós subditos daqueles monarcas ingleses e franceses que son capaces de elevar a súa humana figura ós ceos, facendo miragres curativas; que son así mesmo capaces de rodearse dunha aureola sacra, perfectamente construída, que os sitúa a medio camiño entre os homes e os santos, xa que desa dobre/nobre natureza participan. O impacto sobre os comúns mortais que recibían e eran favorecidos pola sua benéfica acción había de ser extraordinario, e unicamente o racionalismo que se instala en Europa a partir do século XVI resquebraxará a condición sacrosanta dos monarcas franceses e ingleses, nun proceso lento pero seguro.

O camiño iniciado por Bolch nos Reyes... non terá continuadores inmediatos, nin siquera el mesmo volve sobre o tema. Definitivamente, desde os anos 30 a historia económica e social domina a actividade da maior parte dos profesionais occidentais e logo da II Guerra Mundial reafírmase tal tendencia. Nestes segundos Annales ${ }^{7}$ non tivo éxito inmediato a vía das mentalidades aberta por Bloch. De novo a realidade impón, en certo modo, o motivo de interese para o historiador, e logo de 1945 o obxectivo será cuestións como o progreso técnico e económico -que estaban permitindo a Alemaña e Xapón desenvolver unha capacidade de reconstrucción sen precedente, solprendendo e suscitando a necesidade de análise de historiadores e outros científicos sociais-. As similitudes con épocas de progreso e regreso no pasado, revolucións, construccións sociais, estructuras, infraestructuras e superestructuras... reflectiránse en multitude de obras durante os anos 40, 50 e 60, cunha trascendencia e cualidade que non podemos nin debemos dubidar.

\footnotetext{
${ }^{7}$ Os segundos Annales descorren polo económico e social, omitindo outras temáticas propostas por Bloch ou Febvre xa nos primeiros Annales, entre as que evidentemente estaba o estudio do mental.
} 
O período de escurecemento ${ }^{8}$ será simple paréntese trala cal se recupera a historia das mentalidades, afóndase nela, acollendo novas e máis amplias temáticas, especialmente logo dos anos 70, nos chamados terceiros Annales $^{9}$. Claro que a diversidade provocará un problema de definición, ampliamente discutido e difícil de solventar, que durante anos serviu para que os máis críticos e reticentes á historia das mentalidades en Francia — e tamén fóra do país pioneiro-, tomasen esa falla de concreción como criterio suficiente e único para descualificala e deslexitimala por completo, amosando en moitas ocasións un conservadurismo atroz nas formas de facer historia, máis ben debedor do pasado decimonónico ${ }^{10}$. A susceptibilidade e «encastellamento» de certos historiadores repetiráse con cuestións como a interdisciplinaridade e a definición do propio estatus da historia como disciplina de seu, asunto que aínda agora está no punto de mira. Por suposto, haberá que agardar decenios para que se produza de novo un encontro mentalidades-política.

\section{III}

Mais paradoxalmente, ese apéndice atrofiado en que se convertira a historia política, antes «esquelete da historia», recobra forzas cando adopta os métodos, espírito e enfoque teórico das ciencias sociais que a abeiraran

\footnotetext{
${ }^{8}$ En todos eses anos, Philippe Aries, historiador afeccionado, segundo el mesmo se considera, parece o único interesado en abordar o mental, con estudios sobre as actitudes ante a vida e a morte e incluso relativos a infancia. Exemplos son as obras L'histoire des populations françaises et leurs attitudes devant la vie depuis le XVIII siècle (1948), ou L'enfant et la vie familiale sous l'Ancien Régime (1960).

${ }^{9}$ Sobre os terceiros Annales e a historia das mentalidades, ver o artigo de Carlos BARROS, «La contribución de los terceros Annales y la Historia de las mentalidades», en La otra historia. Sociedad, cultura y mentalidades, ed. César GONZÁLEZ MÍNGUEZ Univ. País Vasco, pp. 87-118, 1993. Nel analízanse igualmente algunhas das críticas e erros nos que incorreron, ao tempo que se destacan os seus maiores acertos.

${ }^{10}$ Alain BOUREAU propón restrinxir o obxecto da historia das mentalidades en «Propositions por une historie restreinte des mentalités», Annales ESC, novembro/ decembro 1989 (p. 1.491). Véxase especialmente o artigo de Carlos BARROS en relación a unha definición da historia das mentalidades como historia social das mentalidades: «Historia de las mentalidades, historia social», Temas Medievales, $\mathrm{n}^{\circ} 2$, Bos Aires, 1992, pp. 205-230.
}

"CUADERNOS DE ESTUDIOS GALLEGOS", Tomo XLIII, Fascículo 108, Santiago 1996. 
a un segundo plano. A socioloxía, a antropoloxía ${ }^{11}$, situaron o PODER e o relativo ó mesmo como interese fundamental ó explicar o comportamento de diversas sociedades, actuais ou pretéritas; o problema do poder, universal e eterno, vai máis alá do puramente biográfico/político (reflectido nas biografías «demodé», propias doutras épocas), e do institucionalismo puro e duro practicado por historiadores do XIX e do dereito. A política redímese a través do estudio do poder, que goza do estatus suficiente para suscitar o interese do historiador e así mesmo, coa profundidade necesaria que lle confire entidade para ser obxecto de sesudas interpretacións. Como ben sinala Le Goff,

«la historia política, al transformarse en historia del poder, se convierte en historia en profundidad» ${ }^{12}$.

A recuperación do adxectivo «profunda» para a historia política, gracias á súa transformación en historia do poder, parte do exterior; isto é, o estudio dos símbolos e signos do poder como ocorre na obra de Schramm e tamén na posterior de Kantorowicz ${ }^{13}$. Kantorowicz pretende mostrar que un dos aspectos «maiores» da vida política - centrándose moi especialmente na monarquía británica-, o «asentimento universal cara o estado», enraíza nun proceso metafórico que reflicte unha estructura forte e pouco visible na linguaxe social europea, entre os ss. XIII-XVII. A teoría do dobre corpo do rei, só explícita na versión absolutista no século XVI, aparece como estraña metáfora na que a través dun mesmo ser - o monarca- podemos ler un senso literal (persoa real e concreta) e un figurado (o rei perpetuo). Interesado nos aspectos do simbolismo político medieval, inscríbese na órbita daqueles autores que ó acercarse a examinar actitudes e cerimonias relativas á monarquía medieval, atópanas indefectiblemente enraizadas nunha semioloxía relixiosa que convertía a esfera política en provincia do relixioso. A Coroa ocupa un lugar central como obxecto en si e como obxecto dos ritos de coroación, abranguendo a idea

\footnotetext{
"Ambas se centran no colectivo, comportamentos e actitudes nun ou nuns momentos precisos e nunha sociedade concreta.

${ }^{12}$ En Jacques LE GOFF, art. cit., px. 138.

${ }^{13}$ Ernest KANTOROWICZ, Los reyes taumaturgos, $1^{\text {a }}$ ed. inglesa Londres, 1957. En 1985 publícase a edición española. Céntrase na monarquía inglesa.
} 
abstracta da monarquía. Non nos interesa aquí recensionar a obra de Kantorowicz; só sinalar como o simbolismo político, referido a monarquía, ten unha lóxica de funcionamento e uns elementos que o aproximan enormemente á linguaxe litúrxica e relixiosa; un código coñecido, de aplicación consciente por parte do aparato do poder, que se beneficia así de imaxes e relacións establecidas xa pola Igrexa no seu contacto e dominación sobre os fieis. A través do simbólico, a monarquía recupérase con enfoque diferente, no que o mental xoga papel de primeira orde.

Un novo exemplo da externalidade no proceso de recuperación da historia política - nova - vén dado pola circunstancia de que moitos dos mellores investigadores verbo o simbolismo medieval, e máis concretamente en relación ó exercicio do poder, son en orixe historiadores das relixións, como o caso de Walter Ullmann ${ }^{14}$, a quen se deben investigacións clásicas sobre o poder medieval e especialmente relativas á monarquía. Por tanto, a realeza medieval foi un dos primeiros intereses desa novidosa historia política - agora xa historia do poder - tinxida de métodos comparativos tomados da antropoloxía e da historia das relixións.

A teoloxía política é unha das claves para a comprensión de Idade Media. Mais é necesario ir máis alá. Non basta só con analizar en profundidade as propostas elaboradas desde/polo poder monárquico, neste caso, para sustentar a súa supremacía; tampouco é suficiente explicar os seus postulados, orixes, rastrexar nas fontes vétero e neo testamentarias que os inspiraron, a man que os redactou e o seu papel na engranaxe e creación consciente dun incipiente Estado. Teóricos eclesiásticos primeiro, e laicos máis tarde, adicaron boa parte das súas vidas a elaborar corpus perfectos, sin grietas, nos que nada quedaba á libre interpretación, fieis á voz do seu amo. É preciso, sen dúbida ningunha, comprender e comprobar a súa efectividade, alcance, receptividade... Saen a escena conceptos como manipulación, publicidade — coa que se tenta a venda dun producto, a monarquía, por expresalo en termos modernos e anacrónicos-.

\footnotetext{
${ }^{14}$ Profesor durante anos de historia eclesiástica na Universidade de Cambridge, entre as súas obras están Historia del pensamiento político en la Edad Media, ( $1^{\mathrm{a}}$ ed. inglesa 1965, Harmondsworth, Middlesex), Barcelona, 1983, á que aquí nos referimos; e moitas outras a respecto do poder e pensamiento político medievais, o papado e o seu goberno.
}

"CUADERNOS DE ESTUDIOS GALLEGOS", Tomo XLIII, Fascículo 108, Santiago 1996. 
¿Que imaxe de si tiña a monarquía como institución? ¿Cal era a que pretendía ofrecer? ¿Que mecanismos emprega para chegar a ese público - o conxunto dos súbditos, e tamén outros monarcas europeos especialmente en momentos de loita pola hexemonía no Occidente cristián- afectado de circunstancias similares, mais con diferencias substanciais? ¿Ata que punto se deforma a mensaxe emitida «desde arriba», atravesando unha canle que o conduce ó receptor? A comprensión desa mensaxe variaría segundo sectores sociais e outras variables como proximidade/lonxanía respecto dos centros de poder... ¿Compartíase? ¿Era preciso introducir modificacións na mesma para facela accesible, a través de signos, símbolos externos, rexistro lingüístico empregado a determinados estratos sociais? O papel do receptor, a sua actitude ante a institución que acordan existir desde sempre, xa que por xeracións foi a única forma de goberno que soportaron e viviron...

Por outra banda, a consciencia do emisor, a súa capacidade para elaborar un complicado programa de introducción - paulatina ou non- de determinadas (re)creacións dirixidas a instalarse con forza nas mentalidades, a anclarse no patrimonio das ideas, emocións, e sentementos do que o mental se compón... Unha magna labor, en fin. Son todas elas cuestións que nos sitúan nun nivel máis profundo, en absoluto superficial, que obriga a traballar con conceptos psicolóxicos, sociolóxicos, da teoría da comunicación; a interdisciplinaridade é ineludible. Unha «historia desde abaixo», unha perspectiva diferente e complementaria da «historia desde arriba» multidisciplinar ou non, explicativa ou non, á que estamos máis afeitos.

As investigacións están avanzadas no que se refire a signos e símbolos do poder, cerimonias, rituais... relativos a monarquía. É significativo comprobar como un dos primeiros intereses en tal ámbito foron a morte $\mathrm{e}$ ritos funerarios que acompañan, preceden ou suceden ao monarca na sua postreira viaxe. Hai que ter en conta que as actitudes ante a morte deron pé a boa parte das pioneiras obras en historia das mentalidades, tanto en Francia como nos países ós que se exportou, sendo España un caso que responde perfectamente a tal proceso ${ }^{15}$. Non imos facer aquí unha recopi-

${ }^{15}$ Ver C. QUELLE VIDAL, A.R. FERNÁNDEZ PÉREZ e A. OTERO FERNÁNDEZ, «A Historia das mentalidades na recente historiografía española», en Historia a Debate. Galicia, Santiago, 1995, pp. 143-163.

"CUADERNOS DE ESTUDIOS GALLEGOS", Tomo XLIII, Fascículo 108, Santiago 1996. 
lación bibliográfica en extenso da producción máis salientable dos últimos anos. Outros o fixeron xa, exhaustivamente, con recopilacións comentadas e reflexións interesantes ao respecto ${ }^{16}$. Simplemente sinalar como non é preciso facer grandes esforzos para vislumbrar un certo acercamento, - case espontáneo- do mental e o político, pertinente e necesario.

\section{IV}

Mentres, ¿que ocorre coa historiografía española, e en concreto co medievalismo e a historia política? Completamente abandonada ó labor dos historiadores do dereito e institucionalistas, dos que o medievalista só se liberará nos 70 e 80; só a partir deses anos é capaz de crear «sus propias categorías y sustentar sus investigaciones sobre poderes medievales (...) en la fortaleza de una historia económica y social que guiaba sus pasos en el conocimiento ulterior de la esfera política medieval» ${ }^{17}$.

Esta nova actitude é o camiño a atravesar ata chegar, xa nos 80 e 90, a «incursión del historiador en nuevas temáticas y a una nueva relación y diálogo con otros enfoques no estrictamente socioeconómicos y con otras disciplinas científicas ${ }^{18}$. A antropoloxía é unha interlocutora favorecida nesa apertura, non a única; a interdisciplinaridade da que se gababan en Francia 30 anos atrás chega a España con outros tantos anos de retraso. $\mathrm{O}$ clima político non permitiu que fose doutro xeito; desde logo, era moito máis rendible a tradicional e partidista práctica histórica que se fomentaba desde as institucións pertinentes e se plasmaba nos plans de estudios, en que os mitos fundacionais dunha España gloriosa revivían a cada momento da man dos grandes homes, batallas e enimigos comuns ós que enfrontarse. Nos anos 40, 50 e 60 a producción de historia política res-

\footnotetext{
${ }^{16}$ Ver a aportación de José María MONSALVO ANTÓN co significativo título «Historia de los poderes medievales: del derecho a la antropología (el ejemplo castellano)», Historia a Debate. Medieval, Santiago de Compostela, 1995, pp. 81-151. Entre outras cousas, fai unha magnífica reconstrucción da tarefa historiográfica sobre o tema nos últimos vinte anos.

Ver igualmente nota 15 .

${ }^{17}$ José María MONSALVO ANTÓN, art. cit., p. 82.

${ }^{18}$ Idem.
}

"CUADERNOS DE ESTUDIOS GALLEGOS", Tomo XLIII, Fascículo 108, Santiago 1996. 
pondía a patróns decimonónicos, periclitados, de corte erudito, tradicionalista, superficial e escasamente salientable, de nulo interese analítico ou explicativo.

Paralelamente, e desde principios do século XX, Sánchez Albornoz e outros practican un «xermanismo historiográfico» rigoroso que os converte en debedores do institucionalismo e historicismo, ata o punto de que o centro de gravidade dos estudios históricos desprázase cara as facultades de dereito. Mais o «albornocismo», como ben sinala Monsalvo Antón, «había sido acogido más bien fuera del medievalismo español que dentro de él, y no parecía ser el principal baluarte directo de reconstrucción de los estudios políticos medievales» ${ }^{19}$. Deteñámonos un intre nesas evolucións.

A tendencia iniciada nos 70 e continuada nos 80 é á que Monsalvo se refire como a de reparto de territorio entre xuristas e medievalistas, o cal non deixa de ser significativo; aqueles semellan atraídos exclusivamente polo estudio da administración e o problema do estado, a monarquía...; os segundos polo económico-social, rexeitando a temática da monarquía - salvo «honrosas» excepcións- ata entón restrinxida ó campo dos historiadores do dereito. Novamente o poder dará razón de ser a calquera referencia ó político, como universalidade omnipresente en todo tempo e lugar, manifestada na existencia de determinadas estructuras sociais e de comportamentos económicos precisos; o poder, que se manifesta en calquera aspecto da vida cotiá, en espacios máis o menos reducidos, en «concejos» diversos... A vida «concejil», as súas institucións, goberno, economía, relacións, serán campo fértil do que se colleiten multitude de traballos ó longo de décadas.

Os novos medievalistas que comezan a desenvolver as suas actividades nos anos 70, abrumados polo peso do institucionalismo e a sua dictadura, imposta sobre a propia linguaxe e termos do medievalismo, atopan na economía e sociedade o marco idóneo que propicie a renovación. Tampouco pretendemos negar a importancia de traballos de historiadores do dereito nin menospreciar as súas contribucións. Mais certamente, un dos maiores problemas do medievalista - e por desgracia, recorrente-, foi a incapacidade teorética propia; o emprego de categorías de historiadores do dereito, xuristas, etc. coartou iniciativas e condicionou investi-

\footnotetext{
${ }^{19}$ José María MONSALVO ANTÓN, art. cit., p. 83.
} 
gacións. Claro que hai algunhas obras nos anos 70 que pretenden ofrecer novidosas visións verbo, por exemplo, a monarquía, como pode ser a de Joaquín Jimeno Casalduero, titulada significativamente La imagen del monarca en la Castilla del Siglo XIV, de 1972. Aínda que non responde ás expectativas creadas ${ }^{20}$, Casalduero emprega xa o concepto imaxe como central, mais bota man abusivamente, das fontes escritas, esquecendo agás excepcións - imaxes visuais (iconografía, representacións de cerimoniais) e caíndo na descrición superficial de cuestións, máis relacionadas co acontecemento (narración de feitos que tiveron lugar en cada un dos reinados por el tratados) que con problemas de maior profundidade. Non hai referencia algunha ós efectos que tal imaxe poidera provocar en sectores sociais diversos, ou a súa efectividade, capacidade de planificación do emisor, mecanismos de funcionamento... Non coñecemos nin siquera cal é, verdadeiramente, a imaxe que se enuncia posto que non hai tal contido na obra. Mais ó menos supón un intento de modificar as categorías ata entón empregadas polos medievalistas, o exercicio do poder a través do imaxinario e o seu funcionamento; aínda que se trate dun intento pouco conseguido, un novo concepto entra a formar parte das análises sobre historia política medieval, o de imaxe.

O afondamento nunha historia do poder desde perspectivas do económico-social «que les permite manejar con el estudio de los recursos productivos el medio agrario o las clases, y construir sobre ello las superestructuras $\gg^{21} \mathrm{e}$ os estudios de teoría política - descrición/explicación de ideoloxías complexas, entendidas como sistema, en canto á sua xénese, desenvolvemento, perdurabilidade/mutalibilidade, capacidade de adaptación- ó estilo de Ullmann, cun certo recendo a xurista, tamén se cultivan.

Só nos anos 80 a ata entón maioritaria historia do poder — substituta da tradicional política, evenementielle - experimenta as consecuencias dunha apertura a outras ciencias sociais. A interdisciplinaridade, a aporta-

\footnotetext{
${ }^{20} \mathrm{O}$ emprego do concepto imaxe/imaxinario lévanos a pensar nese «conjunto de representaciones mentales - ante todo reproducciones gráficas: imágenes- por medio de las cuales los hombres reconstruyen un mundo interior distanciado de la realidad material que deviene así realidad inventada», segundo a definición de Carlos BARROS, «Historia de las mentalidades, posibilidades actuales», Problemas actuales de la historia. Terceras Jornadas de Estudios históricos, Salamanca, 1992, p. 3.

${ }^{21}$ José María MONSALVO ANTÓN, art. cit., p. 91.
}

"CUADERNOS DE ESTUDIOS GALLEGOS", Tomo XLIII, Fascículo 108, Santiago 1996. 
ción esóxena, os contactos coa antropoloxía - non novos, recordemos como Le Goff sinala, que foi esta a que dirixiu a historia política cara a historia do poder, fenómeno serodio en España-e outras, xorden con tal forza, que algúns ven perigar o propio estatuto da historia como disciplina e ciencia de seu, ante tanta «altruísta» colaboración e apertura «desmedida». (Actualmente, esta posibilidade/realidade sigue a asustar a moitos e levanta as suas máis airadas críticas). Politólogos, sociólogos, incluso historiadores da arte, colaboran estreitamente, nunha multiplicación de intereses que permite a entrada na escena das mentalidades ${ }^{22}$.

A estreita vinculación desta co poder e o seu exercicio é innegable; o mental supón tamén a percepción da realidade dun xeito determinado e mediatizado, ó tempo que ten un carácter performativo da mesma. Evidentemente, o cambio de actitudes non significa que non continuara a facerse historia política - no máis pexorativo dos sensos-, de mínimo valor e transcendencia. Incluso hoxe se sigue practicando sen rubor.

As diversas representacións, realidades e imaxes do poder son así analizadas en obras dos últimos anos 80, como as de Nieto Soria. En Fundamentos ideológicos del poder real en Castilla, a imaxe ocupa un lugar central na investigación: imaxes sacralizadoras, moralizadoras, organicistas, limitativas e de función... Todas elas teñen importancia propia, xunto con símbolos materiais - Coroa, por exemplo-, propaganda política, etc., nunha meritoria aproximación á complexidade do tema; mais son tamén moitas as obxeccións a presentarlle. O uso indiscriminado de fontes - claro predominio das escritas-, ó seren de cronoloxías diversas (desde o século XII ata o XVI), empregándoas para soster evolucións ou descricións que se dan por existentes; a relativa superficiali-dade das análises que provocan no lector a incertidume lóxica de quen ve coexistir estructuras opostas simultaneamente, no mesmo espacio. Especialmente falla a información sobre a efectividade e incidencia de tales imaxes, a receptividade que xustifica a sua utilidade. É un estudio unidi-reccional, coa consecuente visión sesgada que se nos ofrece. A acción política depende, entre outras cuestións, «de la conciencia, de los sistemas de valo-

${ }^{22}$ Cita José María MONSALVO o proxecto de «Génesis del Estado Moderno», coordenado por Adeline Rucquoi, e especialmente os traballos sobre Castela e Navarra dese plan unitario, desenvolvido a fins dos oitenta.

"CUADERNOS DE ESTUDIOS GALLEGOS", Tomo XLIII, Fascículo 108, Santiago 1996. 
res, de las mentalidades $»^{23}$. E a cultura medieval, tamén a política, reflicte e inflúe ao tempo a acción dos suxeitos sociais. De novo nos atopamos coa «gaiola flexible» que constitúe unha determianda época, coas suas determinacións e novidades para aqueles que a habitan.

Con todo, a veta aberta por este tipo de publicacións sitúa a monarquía como punto de interese e confluencia de conceptos como imaxe, ritual, cerimonial, símbolos... O que constitúe a «mentalidade política» que lexitima a monarquía, un cosmos no que teoloxía, mitoloxía, lenda e ideas diversas - as máis das veces só descritas, pero ó menos apuntadasconforman a complexidade de sociedades e espacios. Por suposto, conceptos tradicionalmente empregados nas máis concienzudas análises dos historiadores-estudosos das ideas (soberanía, unción, diferenciación institución monárquica/monarca, coroa, cetro, etc.) continúan estando presentes, mais inscritos nun todo que dá forza e consistencia a creacións extraordinariamente complicadas e adaptadas ós tempos que se viven.

Tres son as fallas que presenta esta liña de investigación na producción historiográfica española: o descritivismo; o emprego do mental como categoría tan ampla que absolutamente calquera cuestión - especialmente aquelas rexeitadas pola historia tradicional ou ortodoxa (a maior parte das veces sen razón) por non teren a categoría suficiente que lles permita estar en condicións de considerárense obxecto serio da análise histórica- é adscribible a ela; o excesivo seguidismo de estudios similares, especialmente franceses, que impiden a creación de perspectivas propias; e o que é mais grave: partir, normalmente, do que se presume existente. Os intereses da investigacións diríxense ó que se pretende atopar, non se fai lectura inicial de fontes ó fin de determinar o que poden ofrecer. E así, o obxectivo é definir, por exemplo, unha «monarquía tipo» en función de similitudes ou diferencias cos modelos franceses ou británicos. Castela, nese contexto, é unha sorte de periferia, e as categorías de análise que se lle aplican elabóranse en función do foráneo; por exemplo, a existencia ou non de facultades ou poderes taumatúrxicos dos reis casteláns: recoñécese a sua inexistencia, mais enseguida se procuran alternativas á mesma, apresúrase o achádego dun diferente xeito de sacralidade non taumatúrxico, seguramente, mais tan efectivo coma iso. ¡Non é posible que un fenóme-

\footnotetext{
23. José María MONSALVO ANTÓN, art. cit., p. 99.
}

"CUADERNOS DE ESTUDIOS GALLEGOS", Tomo XLIII, Fascículo 108, Santiago 1996. 
no tan sinalado estea ausente na monarquía que é case a máis lonxeva de Europa...!, coidarán algúns, seguramente, alarmados porque a realidade non se acomoda ó que se desexa atopar.

A tendencia sinalada nas liñas anteriores, isto é, o interese polas «mentalidades políticas», e a posterior reivindicación dunha nova historia política - máis ben historia do político-, vencéllase para moitos como Le Goff ou Prochasson ${ }^{24}$ a un fenómeno máis amplo, o chamado dos retornos en historiografía, e parello a reivindicación da biografía (renovada, tamén, e entre outras $)^{25}$ como metodoloxía válida para achegármonos ó coñecemento do pasado. O interese polos suxeitos individuais - fronte ó suxeito colectivo forte, predominante durante os anos 60 e 70 - inspira tamén a derradeira obra de Le Goff; a biografía de San Luis ${ }^{26}$, na que tal e como o autor se ten pronunciado respecto da necesidade de voltar a práctica da historia política - renovada—, o mental e o político, ademais do biográfico, dan a man de maneira convincente e harmoniosa. Non todo é explicable desde a perspectiva da teoría política e da clásica historia das ideas.

Revisando as publicacións dos últimos quince $\operatorname{anos}^{27}$ non se pode negar un certo interese que en institucións de investigación europeas e americanas suscita o tema. Aínda que tamén é certo, cada vez máis o relativo

${ }^{24}$ Véxanse os artigos recollidos en Historia a debate. Tomo III, Otros enfoques, Santiago 1995, pp. 157-167 e pp. 217-237, respectivamente. Actualmente estánse a vivir os cuartos Annales, nos que os retornos marcan a pauta. Esclarecedor a este respecto o artigo de Carlos BARROS, «La contribución de los terceros Annales...», xa citado. Con todo, atravésase na actualidade un momento de reflexión verbo a labor do historiador e a definición da propia disciplina da historia; como mostra, e do mesmo autor, Historiografía fin de siglo, Tórculo 1996, no que se elabora un diagnóstico da realidade historiográfica que atravesamos, ó tempo que se presentan propostas ao historiador.

${ }^{25}$ Interesantes os traballos de Susana STROZZI, «Sujeto y persona en la biografía histórica», en Historia a Debate. Tomo III, Otros enfoques, pp. 175-183, e Xosé Ramón VEIGA ALONSO, Historia a Debate. Galicia, pp. 209-219, respectivamente, en obras xa citadas.

${ }^{26}$ Jacques LE GOFF, Saint Louis, Gallimard, 1996.

${ }^{27}$ Incluímos un apéndice ó final no que se recollen as principais aportacións ó tema dos últimos anos. Para unha información máis completa, é de consulta necesaria a bibliografía incluída no artigo de MONSALVO ANTÓN citado nas notas anteriores; tamén o artigo de QUELLE VIDAL, FERNÁNDEZ PÉREZ e OTERO FERNÁNDEZ, xa citado, referido á producción de historia das mentalidades en España ata 1992-93, no que se fai referencia concreta ás publicacións de interese.

"CUADERNOS DE ESTUdIOS GALLEGOS", Tomo XLIII, Fascículo 108, Santiago 1996. 
a teoría política e do poder está en mans dos politólogos ${ }^{28}$, coroacións, ritos, e mitos siguen presentes, e non é obrigatorio — nen desexablerenunciar a eles; Nieto Soria, Bonifacio Palacios, continúan publicando traballos nesa onda - máis ou menos renovadores-. Carlos Barros, cos seus traballos iniciais verbo historia social das mentalidades - Mentalidade xusticieira dos irmandiños, por exemplo- continuou no artigo «Viva El-Rey! Rey imaginario y revuelta en la Galicia bajomedieval» ${ }^{29}$ nesa liña, mais aportando un xiro fundamental respecto a traballos como os de Nieto Soria. Trátase dunha historia explicativa, desde abaixo, ó tempo que converxen o social e o mental, ademais do político. É fundamentalmente un traballo de historia social das mentalidades no marco de Galicia, espacio periférico a respecto dos centros de poder. Outros autores como Monsalvo Antón negan a existencia dun «imaxinario político»; nin sequera aposta pola relación mentalidades-político. É preciso ante todo consenso para desenvolver cun mínimo de posibilidades esta liña de investigación que liga o social co político e mental, para garantirlle un mínimo de éxito na profesión. Por tanto, é vital convencer ós descrídos - con argumentos válidos, por suposto - das posibilidades do rico panorama que a proposta presenta. O máis recente dos traballos publicados é de novo de Carlos Barros, ;Viva El-Rei! Ensaios Medievais, que presenta — entre outros temas diversos - a vivencia da monarquía desde o ámbito galego, nun libro-recopilación de recente publicación no que mentalidade-política camiñan da $\operatorname{man}^{30}$.

O que ata aquí estivemos describindo, reclamando e propondo é continuar o que Bloch iniciou nos seus Reyes Taumaturgos: as pescudas verbo actitudes políticas mentais. Continuar sen renunciar ó que estudios máis clásicos ou conservadores poden aportar, sen renunciar ó que máis de setenta anos de práctica historiográfica supoñen, coas súas luces e sombras. Como sinala Le Goff no artigo ó que nos estamos a referir constantemente, en tal terreo está case todo por facer. Non cairemos en reduccionismos tipo «toda historia é historia política» — fronte a afirma-

${ }^{28}$ Por exemplo, a obra de Fernando VALLESPÍN (ed.), Historia de la teoría políti$c a$, Madrid, 1991, unha das máis recentes, en varios volumes.

${ }^{29}$ A mentalidade xusticiera dos irmandiños foi publicada en 1988; « $i$ Viva el Rey! Rey imaginario y revuelta en la Galicia bajomedieval», en Studia Histórica, Historia Medieval, $\mathrm{n}^{\circ}$ 12, 1994, Ed. Universidad de Salamanca, pp. 83-101.

${ }^{30}$ Carlos BARROS, , Viva el-Rei!, Ensaios Medievais, 1996, Eds. Xerais. 
cións máis frecuentes do que sería desexable, como «toda historia é historia do dereito», ou «toda historia é historia económica»-. O noso afán non é establecer xerarquías entre historiadores, senón reivindicar unha historia interdisciplinaria, apegada a fontes de todo tipo, sen preseleccións nen «codificacións». Nun intre como o actual, en que moitos piden a revisión do obxecto da historia das mentalidades e a sua delimitación ${ }^{31}$ de xeito que non perda peso, certo estatus e obxectos propios - que en ocasións cedeu ou se independizaron da rama mai-, é unha boa ocasión de revindicar a práctica e a necesidade dunha historia das actitudes políticas mentais. Máis que nunca, a confluencia do político e do mental é indispensable.

Do mesmo xeito, na nosa reivindicación incluése o desexo de outorgar ó acontecemento o lugar que mereza, máis o menos transcendente segundo os casos, sen negarlle de partida o dereito a ser máis que simples ilustración e anécdota. Por suposto, en absoluto propomos a simpleza narrativa o episódica — para iso existen as novelas históricas, excelente entretenemento-, senón a necesidade de situar o concreto, único e irrepetible no espeso magma da longa duración. Desde logo, o camiño é longo e moito queda por percorrer.

${ }^{31} \mathrm{O}$ artigo publicado por Alain BOUREAU, «Propositions por une histoire restreinte des mentalités», en Annales, novembro/decembro de 1989 (p. 1.491), sinala como a historia das mentalidades foi relegada pola antropoloxía histórica, á que curiosamente asignara un obxecto propio. O invasionismo doutras ciencias sociais baleirouna de contido; «as mentalidades son o que queda na marmita da historia cando se retiran a carne e os legumes - acontecementos e obxectos «duros»- Na escuma da ebullición atópase o pobo, as mulleres, o sexo, o corpo, etc.». Os obxectivos iniciais das mentalidades foron arrabatados por outras disciplinas ou ben chegaron a ter tal independencia e substanciación que se desgallaron, constituíndose en micrototalidades - historia das mulleres-. Finalmente, os herdeiros de Febvre, renuncian a outorgar un contido determinado ás mentalidades; promóvena ó rango dunha instancia interna e colectiva de percepción e decisión, do lado dos sentementos e dos afectos. Os sentementos son as ideas dos pobres - consideran-, que forman a maior parte da poboación e ademais son os verdadeiros suxeitos da historia. Fronte a iso, as ideas pertencen ó singular, non son aptas para a explicación histórica.

De aí que para Boureau, sexa posible que se consideren sen rubor historia política ou social obras «das mentalidades» como Los reyes taumaturgos de Bloch, o Rabelais de Febvre e outras, coa consecuente perda de entidade para a historia das mentalidades.

Véxase moi especialmente o artigo de Carlos BARROS, «Historia das mentalidades, historia social», art. cit., varios anos posterior e no que se clarifica extraordinariamente as vías posibles a seguir pola historia das mentalidades, ligada sempre ó social.

"CUADERNOS DE ESTUDIOS GALLEGOS", Tomo XLIII, Fascículo 108, Santiago 1996. 


\section{BIBLIOGRAFÍA}

BARROS, Carlos: «Historia de las mentalidades: posibilidades actuales», Problemas actuales de la historia, Terceras Jornadas de Estudios Históricos, Salamanca, 1992.

BARROS, Carlos: «Historia de las mentalidades, historia social», Temas Medievales, n² 2, Buenos Aires, 1992, pp. 205-230.

BARROS, Carlos: «La constribución de los terceros Annales y la historia de las mentalidades. 1969-1989», en La otra historia. Sociedad, cultura y mentalidades, César GONZÁLEZ MÍGUEZ (ed.), Universidad del País Vasco, 1993, pp. 87-118.

BARROS, Carlos: « $i$ Viva el Rey! Rey imaginario y revuelta en la Galicia bajomedieval», en Studia Historica, Historia Medieval, n 12, 1994, Ed. Universidad de Salamanca, pp. 83-101.

BARROS, Carlos: ;Viva el Rey! Ensaios medievais, Eds. Xerais, 1996.

BARROS, Carlos: Historiografía fin de siglo, Tórculo 1996.

BLOCH, Marc: Los reyes taumaturgos, $1^{\text {a }}$ ed. española, México 1988.

BOUREAU, Alain: «Propositions por une histoire restreinte des mentalités», Annales ESC, 1989, Nov/Dec, p. 1.491 e ss.

GIMENO CASALDUERO, Joaquín: La imagen del monarca en la Castilla del Siglo XIV, Madrid, 1972.

KANTOROWICZ, Ernst: Los dos cuerpos del rey. Un estudio de teología política medieval ( $1^{\mathrm{a}}$ ed. inglesa 1957). Madrid, 1985.

LE GOFF, Jacques: «¿Es la política el esqueleto de la historia?», $\left(1^{\mathrm{a}} \mathrm{ed}\right.$. francesa 1971); en Lo maravilloso y lo cotidiano en el Occidente Medieval, Gedisa, 1988.

"CUADERNOS DE ESTUDIOS GALLEGOS", Tomo XLIII, Fascículo 108, Santiago 1996. 
LE GOFF, Jacques: «Le retours dans l'historiographie française actuelle», Historia a Debate, Tomo III, Otros enfoques, Santiago, 1995, pp. 157 167.

LE GOFF, Jacques: Saint Louis, Gallimard, 1996.

MONSALVO ANTÓN, José María: «Historia de los poderes medievales. Del derecho a la antropología», Historia a Debate. Medieval, Santiago, 1995, pp. 81-149.

NEITO SORIA, José Manuel: Fundamentos ideológicos del poder real en Castilla (siglos XIII al XV), Madrid, 1988.

PROCHASSON, Christophe: «Vingt ans d'histoire politique en France», Historia a Debate, Tomo III, Otros enfoques, Santiago 1995, pp. 209217.

QUELLE VIDAL, César; FERNÁNDEZ PÉREZ, Ana; OTERO FERNÁNDEZ, Araceli: «A historia das mentalidades na recente historiografía española», Historia a Debate. Galicia, Santiago, 1995, pp. 143-163.

SCHAUB, Jean Frederic: «L'Histoire politique sans l'État: mutations et réformulations», Historia a debate, Tomo III, Otros enfoques, Santiago 1995, pp. 217-237.

ULLMANN, Walter: Historia del pensamiento político en la Edad Media, (1 $1^{\text {a }}$ ed. inglesa 1965), Barcelona, 1983.

VEIGA ALONSO, Xosé Ramón: «A biografía histórica no século XX. Unha aproximación dende a práctica», Historia a Debate. Galicia. Santiago, 1995, pp. 209-219.

"CUADERNOS DE ESTUDIOS GALLEGOS", Tomo XLIII, Fascículo 108, Santiago 1996. 


\section{APÉNDICE BIBLIOGRÁFICO ${ }^{32}$}

ABULAFIA, David: Federico II. Un imperatori medievale, Torino, Einaudi, 1990.

BACHRACH, Bernard S.: Armies and Politics in the Early Medieval West, Vermont, 1993.

BAK, János M.: (ed.), Coronations. Medieval and Early Modern Monarchic Ritual, Berkeley, Univ. California Press, 1990.

BALIÑAS, Carlos: Defensores e traditores: un modelo de relación entre poder monárquico e oligarquía na Galicia altomedieval (718-1037), 1988.

BARROS, Carlos: « $i$ Viva el Rey! Rey imaginario y revuelta en la Galicia bajomedieval», en Studia Histórica, Historia Medieval, n 12, 1994, Ed. Universidad de Salamanca, pp. 83-101.

BARROS, Carlos: ¡Viva el Rey! Ensaios Medievais, Vigo, 1996.

BERCÉ, Yves-Marie: Le roi caché. Sauvers et imposteurs. Mythes politiques populaires dans l'Erope Moderne, Paris, Librairie Arthème Fayard, 1990.

BIZARRI, Hugo Óscar: «Otro espejo de príncipes: Avisación de la dignidad real», Incipit, Buenos Aires, nº 11, 1991, pp. 187-208.

\footnotetext{
${ }^{32}$ Recollemos aquí os últimos traballos dos que temos noticia a través de publicacións periódicas e anuarios dispoñibles na Facultade de Xeografía e Historia de Santiago de Compostela, nos últimos dez anos, e non consignados nas recopilacións ás que fixemos referencia nas páxinas precedentes; ben por seren de recentísima publicación, ben por tratarse de artigos publicados en revistas diversas dos que non se fixeron eco os autores das compliacións recomendadas. Non son específicamente referidos a «actitudes mentais políticas», senón estudios diversos verbo aspectos simbólicos, imaxinario, iconografía, etc., das monarquías medievais occidentais; algúns exceden ese marco cronolóxico, pero o seu interese xustifica a inclusión.
}

"CUADERNOS DE ESTUDIOS GALLEGOS", Tomo XLIII, Fascículo 108, Santiago 1996. 
BLACK, A: Political Thought in Europe (1250-1450), Cambridge, Cambridge Univ. Press, 1992.

BOUREAU, Alain, and INGERFLOM, Claudio Sergio (eds.): «La royauté sacrée dans le monde chrétien», Coloque de Royaumont, mars 1989 (L'histoire et ses représentations, 3), París, Ecole des Hautes Etudes en Sciences Sociales, 1992.

BOUREAU, Alain: «Les céremoines royales françaises entre performance juridique et compétence liturgique», no 6 Annales ESC, 1991, pp. 1253-1264.

BRABANT, Margaret: (ed.), Politics, Gender and Genre: The Political Thought of Christine de Pizan, 1992.

BURNS, J.H.: Lordship, Kingship and Empire: The Idea of Monarchy 1400-1525, The Carlyle Lectures. Oxford, Oxford Univ. Press, 1992.

CONTAMINE, Philippe: «Le royaume de France ne peut tomber en filles», Une theorie politique a la fin de la Moyen Age, 1993.

DA MOTA, Isabel María H.F.: «A imagem do rei na 'Historia Genealogica' da Casa Real portuguesa. Um estudio preliminar», en Revista de História das Ideas. Cultura, política, mentalidades, 1989, nº 1.

DEAN, Carolyn: «Inconscio e immaginario politico», Societa e Storia, $1994, n^{\circ} 65$, pp. 637-643.

DUCHARDT, Heinz; JACKSON, Richard A. e STURDY, David (eds.): European Monarchy: Its Evolution and Practice from Roman Antiquity to Modern Times, Stuttgart, 1992.

DUNBABIN, Jean: «What's in a name? Philip, King of France», Speculum, vol. 3-4, pp. 949-965, 1993.

FEROS, Antonio: «Vicedioses pero humanos: el drama del Rey», Cuadernos de Historia Moderna, $\mathrm{n}^{\circ}$ 14, Ed. Complutense, Madrid, 1993.

"CUADERNOS DE ESTUDIOS GALLEGOS", Tomo XLIII, Fascículo 108, Santiago 1996. 
GHISALABERTI, Alessandro: «Politia in Tommaso d'Aquino e Marsilio de Padova», Studi Ummanistici Piceni, pp. 109-114, 1994.

GILLINGHAM, John (ed.): Richard III: A medieval Kingship, New York, St. Martin's Press, 1993.

GRABOIS, Aryeh: «Un mythe fondamental de l'histoire de France au Moyen Age: le roi David, précursor du roi trés chrétien», Revue Historique, 1992, pp. 11-31.

GUREVITCH, Aaron: Historical Anthropology of the Middle Ages, ed. Jana Howlett, Chicago \& London, Univ. of Chicago Press, 1992.

HEDEMAN, Anne D.: The Royal Image: illustrations of the «Grandes Chróniques de France» (1274-1422), 1993.

HERWING, Wolfram: «Political Theory and Narrative in Chartres», Viator, 1995, pp. 39-53.

HULSE, Lynn: «The King's Entertainment» by the Duke of Newcastle», Viator, 1995, pp. 333-355.

KAWA-TOPOR, Xavier: «L'image du roi dans le Roman de Renart», Cahiers de Civilisation Médiévale, xullo-setembro 1993, $\mathrm{n}^{\circ} 3$.

KING, John N: Tudor Royal Iconography. Literature and Art in the Age of Religions Crises, Princeton Univ. Press, 1989.

KLANICZAY, Gabor: L'image cheveleresque du saint roi a XIIe siécle, Acts Congrès Royaumont, mars 1989 (L'histoire et ses représentations, 3), París, Ecole des Hautes Etudes en Sciences Sociales, 1992.

KNOWLES, David: The evolution of Medieval Thought (ss. XI-XIV), London, 1988.

KRYNEN, Jacques: L'Empire du roi: idées et croyances politiques en France: XIIIe-XVe siécle, Gallimard, 1993.

"CUADERNOS DE ESTUDIOS GALLEGOS", Tomo XLIII, Fascículo 108, Santiago 1996. 
LANDER, J.R.: The limitations of English Monarchy in the Latter Middle Ages, The 1986 Joanne Goodman Lectures, Toronto, Univ. of Toronto, 1989.

LE GOFF, J.: «La sainteté de Saint Louis; sa place dans la typologie et l'évolution chronologique des rois sants», en La fonction des saints dans le monde occidental (IIIe-XIIIe siécle), Actes du colloque organisé par l'Ecole de Rome avec le concours de l'Université de Rome, outubro 1988.

LE GOFF, J.: The Medieval Imagination, The University of Chicago Press, 1993.

LE GOFF, J.: «Aspects religieux et sacré de la monarchie française du Xe a XIIIe siècle», Pouvoirs et libertés a temps des premiers Capétiens, pp. 309-322, Malevrier, Herault, 1992.

LE GOFF, J.: Saint Louis, Gallimard, 1996.

MEGÍAS QUEIRÓS, José J.: La teoría política entre la Edad Media y la Edad Moderna, Universidad de Cádiz, 1992.

MÉRINDOL, Christian de: «Le prince et son cortége, la théatralisation des signes du pouvoir á la fin du Moyen Age», en Les princes et le pouvoir au Moyen Age. XXIII Congrès de la S.H.M.E.S. (Brest, Mai 1992). Public. de la Sorbonne, 1993.

MOEGLIN, Jean Marie: Les ancètres du prince. Propaganda politique et naissance d'une histoire nationale en Baviére au Moyen Age (11801500), Genève, Droz, París, EPHE, IV Section, 1985.

NELSON, Janet L.: Charles the Bald. London, 1992.

NELSON, Janet L.: Politics and Ritual in Early Medieval Europe. London, The Hambledon Press, 1986, vol. 1.

PEGGS, Mark Gregory: «Le corps et l'autorité: la lépre de Badouin IV», Annales ESC, 1990(2), pp. 265-267.

"CUADERNOS DE ESTUDIOS GALLEGOS", Tomo XLIII, Fascículo 108, Santiago 1996. 
PENNINGTON, Kenneth: The Prince and the Law, 1200-1600, Berkeley, Los Ángeles, Oxford: Univ. of California Press, 1993.

PETERS, Edward: «The infancy of celebrated nations: folk, Kingdom and state in Medieval Erope», Medieval Perspectives, pp. 18-37, 3:2 for 1988 (1991).

PETERS, Edward: The shadow King. Rex Inutilis in Medieval Law and Literature (751-1327), 1990.

POLLINI, Nadie: La mort du prince: Rituais finéraries de la Maison de Savoie (1343-1451), Foundation Humbert II et Maria Jose de Savoie. Cahiers Lausannois d'Historie Médiévale, 9. Lausane, Univ. Laussane, 1994.

REGALADO, Nancy Freeman: Allegories of power: the Tournament of Vices and Virtues in the Roman de Favel, 1993.

REYDELLET, Marc: La royauté dans la littératre latine di Sidoine Apollinaire Isidore de Séville, 1986.

SANZ HERMIDA, Jacobo: «Literatura consolatoria en torno a la muerte del príncipe Don Jan», Studia Historica, Historia Medieval, 1993, pp. 157-171.

SOT, Michel: «Heredité royale et pouvoir sacré avant 987», Annales ESC, 1988 (Maio-Xuño), p. 705.

SUBRENAT, Jean: «Un point de vue sur la fonction royale sous PhilippeAuguste: le roi Noble dans le Roman de Renart», Histoire et Société, III, pp. 167-177.

VELLARE, Catherine Simonne: Constitutional Theory and the responsabilities of Kingship in the Monastic Chronicles of Anglo Norman England, Mississipi, State University, p. 1990.

"CUADERNOS DE ESTUDIOS GALLEGOS", Tomo XLIII, Fascículo 108, Santiago 1996. 
WARNER, David A.: «Thietmar of Merseburg on Rituals of Kingship», p. 53-57, Viator, 1995.

WOOD, Charles: «La mort et les funérailles d'Henri II», Cahiers de Civilization Medievale, XXXVII, 1994, pp. 119-123. 